\title{
The Spread of Gig Economy: Trends and Effects
}

\author{
Nilanjan Banik \\ Professor, nilanjan.banik@bennett.edu.in \\ Milind Padalkar \\ Professor, milind.padalkar@bennett.edu.in \\ Bennett University, Plot Nos 8-11, TechZone II, Greater Noida 201310,Uttar Pradesh, India
}

\begin{abstract}
The development of online communication platforms has given rise to the phenomenon of the gig economy. A new economic model that embraces a variety of forms of short-term employment is rapidly spreading around the world, becoming an everyday reality and transforming the labor market. The article analyzes the factors influencing the dynamics of this process and its main effects. Testing the main hypothesis showed that the development of technological infrastructure, despite its importance, does
\end{abstract}

Abstract
Keywords: gig economy; technology index; income distribution; digital platforms; labor markets; corporate strategies not fully explain the unevenness of the penetration of the gig economy and the variations in its impact upon different sectors, professions, and skill levels.

Gig economy drivers are subject to further study, but already now we can state the need for targeted measures to adapt the economy to the new model, including retraining or creating alternative employment opportunities for "traditional" workers giving up jobs in favor of gigemployed ones.
Citation: Banik N., Padalkar . (2021) The Spread of Gig Economy: Trends and Effects. Foresight and STI Governance, 15(1), 28-38. DOI: $10.17323 / 2500-2597.2021 .1 .19 .29$ 
$\mathrm{F}$ ollowing the 2008 global financial crisis and the resultant rise in unemployment, many professionals and skilled workers began performing shortterm jobs to earn their livelihood. This phenomenon was described as the 'gig economy', a metaphor drawn from the music industry where artists performed gigs. ${ }^{1}$ The spread of gig work was initially driven by skilled IT professionals who began using online digital platforms to search for such opportunities. Gig work is emerging as a livelihood option for job seeking students, retirees, low- and high-skilled workers. Working with US employment data, Collins et al. [Collins et al., 2019] find virtually all expansion of the gig workforce since 2011 has come from online platform work. The expansion of the gig phenomenon has attracted the interest of researchers. Different descriptions have been offered towards for a clearer understanding of this phenomenon. There are various definitions that do not always coincide with practical approaches when it comes to the gig economy. Scholars also note the definitional difficulties associated with the platform economy - a term which is close to gig economy [Frenken, Schor, 2019].

Based on the existing literature, we draw upon the major characteristics of the gig economy, comment on its implications for labor productivity, employment growth, income distribution, and corporate strategies. Then we discuss the legal implications of the rise of the gig economy in India. Also, we examine the hypothesis that Information and Communications Technology (ICT) infrastructure plays a positive role in the spread of gig work by constructing a Technology Index (TI) encompassing mobile, internet, broadband connectivity, and electricity connections. Finally, based on our results we conclude with some policy recommendations.

The report by the World Bank [World Bank, 2015] categorizes the gig economy into three types of outsourcing activities such as Microwork, Freelancing, and Business Process Outsourcing. Meanwhile, drawing from the empiricist tradition the term 'gig economy' exhibits a few other characteristics. First is that gig work tends to be on-demand and short-term [Berg, 2016; Van Doorn, 2017]. It is priced by pre-defined outcomes and depending upon how much one earns, gig work is also referred to as the 1099 economy $^{2}$ [Kalleberg, Dunn, 2016].

There are no clear definitions for "short term" and "short-term contract". Gig workers may work for one year or more, under serially renewed fixed-term contracts, and yet fall under the classification of shortterm contracts [Connelly, Gallagher, 2006].

A characteristic feature of the gig economy is that it is platform-enabled [Kenney, Zysman, 2016]. The gig economy uses technology platforms as conduits to connect the workers to the hirers, and the owners of assets to the customers. The first category is the transaction happening using a labor platform and the second is the transaction happening through a capital platform [Farrell, Greig, 2016].

Examples of labor market platforms are Uber, Task Rabbit, Swiggy, Zomato, among others. As the work is job-specific, workers using these platforms have the flexibility to work for more than one contractor. A food delivery person can work for both Swiggy and Zomato, and yet can drive Uber during some other time. Similarly, the aggregators may provide more than one type of service. For example, Uber which is generally known as a taxi service aggregator also has Uber Eats which is a food delivery and online take-out service app. The examples for capital market platforms are service providers such as Airbnb, which serves house owners in renting out temporarily free living space. Similar is the case with car rental service platforms such as Zipcar and Hertz.

The next characteristic is about scalability and the absence of entry barriers. The platform-enabled gig economy can accommodate a large number of buyers and sellers. The cost of entering a platform-enabled market is minimal. According to [Drahokoupil, Fabo, 2016], digital platforms have lowered the transaction cost of labor outsourcing and temporary access to goods and services. The gig economy has helped to reduce information asymmetry associated with job search costs [Zhao, 1999]. In India, for example, before the advent of the digital world, job seekers regularly waited in line - sometimes all day - to register at national employment exchanges for their job search. At present, digital platforms allow the job seekers to conduct most of the search and inquiry processes online. Finally, the gig economy usually operates on the basis of 'standardized' outcomes. As the job performed is outcomebased, the risks associated with moral hazard or asymmetric information are mitigated. For instance, in the case of a long-term contract, persons once hired cannot be fired without serving a notice period or trade unions agreeing to such a decision. The onus of risk associated with employee's output falls upon the employers. In the gig economy driven by task-based jobs, problems associated with information asymmetry and/ or moral hazard generally do not arise. The rating systems on platforms for task-based services also ensure that only the most standardized and efficient suppliers get rewarded in the long-run.

Given these aforementioned characteristics and based on the work arrangement that the gig economy has to offer, it is spreading fast. According to US Bureau

\footnotetext{
The Cambridge dictionary defines 'gig' as 'a single performance by a musician or a group of musicians'. See: https://dictionary.cambridge.org/dictionary/ english/gig; accessed on 23 July 2020.

${ }^{2}$ Named by the title of the 1099-MISC tax form, which any American company is required to issue for a freelance employee whose income exceeds USD600.
} 
of Labor Statistics, there are 1.6 million gig economy workers working for services such as Uber, TaskRabbit, and others. ${ }^{3}$ Worldwide, major demand for gig work arises from Information Technology (IT), IT-enabled services, e-commerce, retail, hospitality, and the fastmoving consumer goods (FMCG) sector, wherein sudden and short-duration workers at the lateral levels are very much in demand [AfDB et al., 2018]. In 2015, some of the in-demand jobs dealt with internet marketing, blogs, and e-commerce jobs. There were about 26,000 open jobs paying hourly rates between $\$ 16$ and $\$ 22$ on average [World Bank, 2015]. The digital platforms are creating additional job opportunities for employees working in the traditional brick-and-mortar economy. Collins et al. [Collins et al., 2019] find that in the US, the share of the workforce with income from gig work has grown by 1.9 percentage points of the workforce between 2000 and 2016. In the overall gig economy, about $60 \%$ of the workforce also have a fulltime salaried income over the course of year.

\section{The Impact of Gig Economy}

The rise of technology, cheap labor, and entrepreneurial spirit is aiding the growth of the gig economy. The platforms enable workers to connect across geographical boundaries. Consequently, the outcomes are raising productivity and optimizing employment and income distribution. In this section, we consider these dimensions in detail.

\section{Productivity and Specialization}

The rise of the gig economy is likely to increase overall productivity due to the increase in labor force participation rates and improved access to lower-wage workers from abroad, leading to more specialization and standardization of work. For instance, over the last few decades, Europe has been witnessing an ageing society and a fall in labor productivity. With falling birth rates and an ageing population, it is difficult to increase productivity through traditional labor force participation methods. The population growth rates in many Eurozone countries have fallen below the required replacement rate threshold of 2.1. For instance, the net population growth rates are 1.38 for Greece, 1.39 for Spain, 1.41 for Italy, and 1.94 for the UK. It is estimated that for Spain and Greece, the over-65-year-old population will increase from around $17 \%$ to $25 \%$ by 2030 [Banik, 2019]. An ageing society with strong trade unions finds it difficult to increase worker productivity [Sherk, 2009]. ${ }^{4}$ However, this is likely to change with the spread of gig work which increases productivity by increasing labor participation through digital platforms. Rather than hiring one generalist to complete all tasks, companies can designate tasks to various
Figure 1. Source of Labor

Productivity Growth (\%)

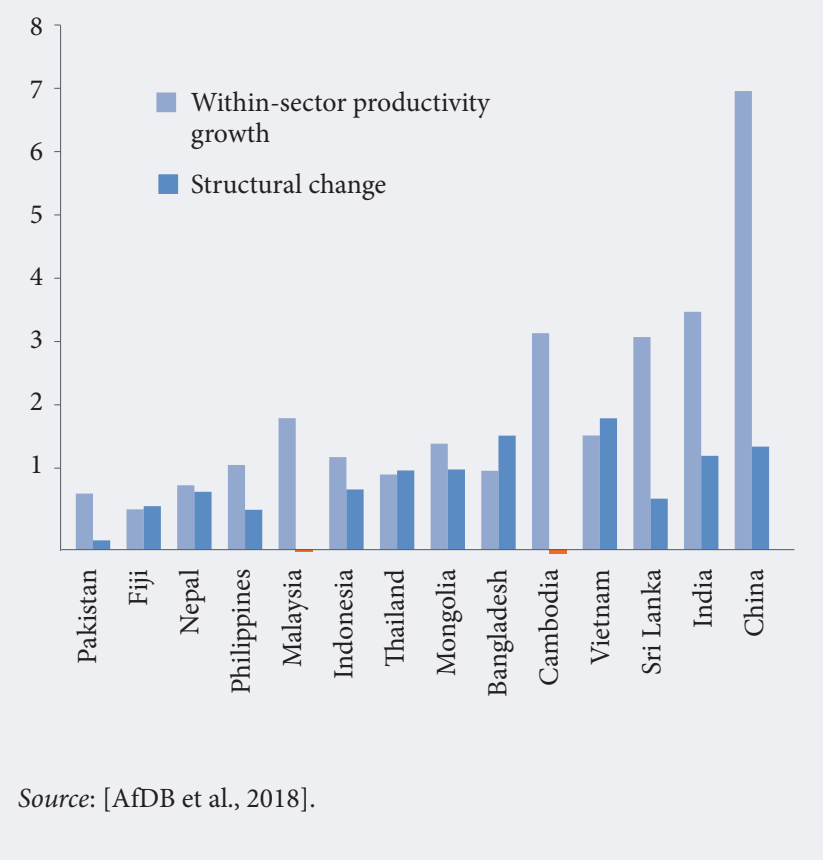

freelancers specializing in that area. Workers are also more accountable as performance standards dictate future incomes. Connected global labor markets will lead to a rise in economic productivity even in countries in Europe which now have a shortage in the supply of labor. Workers from labor-abundant developing countries are likely to gain. Owing to the standardized rules, in a gig world, low-salaried service workers from developing countries can now earn more by engaging in similar job profiles in established economies. There are no entry barriers and all that is needed is access to mobile/internet and electricity connections. The rise in labor productivity, as well as an increase in percapita income can happen not only because of presence in gig work but also from the structural transformation brought in through technological innovation [Bassanini, Scarpetta, 2002]. (Figure 1)

\section{Employment and Labor Participation}

Labor participation in a gig world comes from a variety of sources. The lower-income individuals are more likely to participate on labor platforms than higher-income counterparts [Farrell, Greig, 2016]. As of 2016, $0.6 \%$ of the people in the lowest income quintile earned income from labor platforms such as Upwork and Uber, whereas the remaining $0.4 \%$ is dependent on capital platforms like Airbnb. This lower income group is also more persistent in using the labor platform: $56 \%$ of the participants in the lowest in-

\footnotetext{
See: https://usafacts.org/articles/what-gig-economy/\#: :text=the\%20United\%20States\%3F-,According\%20to\%20the\%20Bureau\%20of\%20Labor\%20 Statistics\%2C\%20there\%20are\%201.6,1\%25\%20of\%20the\%20US\%20workforce; accessed 27 July 2020.

${ }^{4}$ An ageing country is one with $10 \%$ or more of its population above 60 years of age. See [Sherk, 2009].
} 
come bracket continued accessing the platform within 12 months compared to $47 \%$ of middle-income participants, and $40 \%$ from the highest income quintile. There are no barriers based on caste, religion, gender, and location. Women comprise more than a third of the 15,000 users of the digital platform Souktel in the West Bank and Gaza region, but only 19\% of the entire labor force in the same area. ${ }^{5}$ In the US, before the advent of Airbnb, African American rental hosts were getting $12 \%$ less rent than their white American counterparts for the same type of house in the same location [Edelman, Luca, 2014]. ${ }^{6}$ Spatial location of workers whether urban, rural, or small towns does not matter. Online labor markets such as Freelancer and Upwork are likely to substitute for physical labor migration and hence the uptake in working opportunities on digital platforms. The gig jobs have a spill-over effect not only on labor markets [World Bank, 2015; Gomez-Herrera et al., 2017]. For example, after the introduction of taxi services by Uber and Ola, taxi fares were reduced in major cities in India [Pandya et al., 2017]. The gig economy has other societal benefits such as a reduction in motor vehicle accidents and traffic congestion [Greenwood, Wattal, 2017] and the improvement of air quality [Tran, Sokas, 2017].

\section{Income Distribution}

The benefits from the advent of the gig economy as a complex and ambiguous phenomenon are not uniformly distributed. Full-time employment in the gig economy may lead to lower-income and economic vulnerability for lower-skilled workers in developed countries [Bergman, Jean, 2016]. As the workers from less developed countries get connected to the potential recruiters in developed regions, their wage rates are likely to increase at a faster rate. Similarly, a lowskilled worker from the developed country is likely to lose out in the presence of global competition. Things may get more difficult for these unskilled laborers in the presence of technological innovation. This leads to a skewed income distribution globally. For example, a rise in wage inequality in Germany results from firms paying more to their highly skilled workers in comparison to the others [Card et al., 2013]. As the availability of highly skilled and talented workers are limited, wage premium increases. In the US, the reason for wage inequality has to do with more competitive firms tending to keep their highly skilled laborers as full-time workers, by paying a wage premium. The low-skilled work is outsourced, both in the US, as well as in other developed countries including Sweden, Japan, and the United Kingdom, typically as gig work.
An International Labor Organization report suggests that gig workers are making less than the governmentmandated minimum wage rate [ILO, 2018]. About two-thirds of the US workers using the Amazon platform made less than the federal minimum wage rate of $\$ 7.25$ an hour and only 7\% of Germans on the Click worker platform made the statutory minimum wage of 8.84 Euros (\$10.40) an hour. ${ }^{7}$ Virtual "sweatshops" created by technology platforms are largely unregulated with no floor on minimum wage rates. The workers do not have access to other fringe benefits such as health insurance, sick leave, working hours, the continuation of contracts, and settlement of disputes [Chandy, 2017]. Currently platform services are coming under increasing pressure to adhere to the rules that are applicable to traditional service providers in those fields. The city of Seattle has passed a law permitting Uber and Lyft drivers to unionize and the drivers receive unemployment benefits. ${ }^{8}$ In a court ruling against a garment manufacturer in India, the Supreme Court of India passed a judgment stating that female contractual laborers who are working from home doing piece work would be considered "employees" of the company who has engaged them to do work [Kumar, 2019].

Another possible source of unequal income distribution arises from ownership of capital platforms. Although platform software has become ubiquitous, the market valuation of companies such as Uber, Airbnb, Facebook, and Amazon, put together, may in fact be higher than the GDP of many low-income countries. The drivers hired by Uber in the US were embroiled in a long-drawn legal battle, arguing they should be treated as employees and not as an independent contractors, with a better non-pecuniary benefit [Lobel, 2016]. For instance, although drivers using the Uber platform are paid by the job and have control over their work hours and geographical preference for operation, Uber set the passenger pay-rate and displaced the drivers falling below a minimum rating point. Drivers filed a class-action suit during 2013, with Uber finally agreeing to pay $\$ 20$ million to settle the case in $2019 .{ }^{9}$

Exogenous shocks, such as COVID-19, can also change distribution of income. In a survey conducted by APPJOBS, comprising of 1,400 workers from 58 different countries, the study finds the sectors which benefitted from the pandemic includes delivery, consulting, freelancing, and online surveys. Whereas the in-person sectors, such as house sitting, babysitting, driving, and hospitality (hotel and tourism) industries, were negatively impacted [AppJobs, 2020].

\footnotetext{
${ }^{5}$ https://blogs.worldbank.org/developmenttalk/narrowing-gender-gaps-through-online-job-matching-how-does-souktel-do-it, accessed 19.02.2021

${ }^{6}$ However, the organized labour market comes with a tag of equal opportunity employer, wherein the employer agrees not to discriminate against employee or job applicants because of race, national origin, and gender. See [Edelman, Luca, 2014].

https://www.bloomberg.com/view/articles/2017-01-19/europe-stands-up-for-gig-economy-workers. Accessed 21 April 2020.

${ }^{8}$ See: https://www.nytimes.com/2015/12/15/technology/seattle-clears-the-way-for-uber-drivers-to-form-a-union.html; accessed 20 April 2020

9 See: https://techcrunch.com/2019/03/12/uber-agrees-to-pay-drivers-20-million-to-settle-independent-contractor-lawsuit/; accessed 19 June 2020
} 


\section{The Impact of the Gig Economy on the Organizational Environments}

The largest impact of the gig economy occurs in the areas of corporate strategies and performance management. In the traditional organizational forms, whether hierarchical, matrix, or network, the work is broken down into discrete units and allocated to workers in logical sequences of assembly-type dependency structures to ensure a swift, even flow [Schmenner, Swink, 1998]. However, the real-life organizations experience sub-optimal performance due to structural imperfections, incomplete specifications of work elements, coordination delays, and ambiguity experienced by the human element. Organizations compensate for such imperfections by building buffers of extra manpower and skills by calibrating the processes of worker selection and allocation. The dynamic of work expansion or contraction leads to the uneven absorption of such extra manpower adding to the coordination problems. In practice, therefore, the work environment of most organizations is plagued by overstaffing and understaffing at different stages of work cycles. The net effect of such a dynamic is a patchwork of idle time within the organizational environments. The idle time occurs both during the switchover between the tasks as well as endogenously within the tasks due to workers pacing their work differently under different conditions [Gevers et al., 2006, 2015; Brodsky, Amabile, 2018]. Such idle time in an unevenly overstaffed organization is of serious concern to the management teams, who often employ various methods to plan work to maximize throughput.

The advent of the gig economy and availability of gig workers or freelancers represents an opportunity for managers to package work differently and assign it to gig workers through online platforms. While such assignments take the form of short-term engagements, they are different from outsourcing which generally consists of semi-permanent arrangements of non-core activities performed through business-to-business contracts and are paid on the basis of defined inputs or outcomes. Gig work on the other hand involves the element of choice on part of the gig worker, short-term contracts, and payment on the basis of pre-defined outcomes and typically are covered by person-to-person or by business-to-person contracts. For instance, the consulting firms working on complex contracts require specific subject matter experts. Such experts are rarely employed with anyone on a full-time basis; instead, the firms obtain them through gig channels. Thus, the gig work can consist of high expertise as well as commodity services such as canteen work, security, courier, transportation, and so on. Such a broad scope poses both challenges as well as opportunities for the operating management, who must develop the orga- nizational capability to plan, decouple, and define the work packages, participate on the digital platform to select the gig workers, assign the work, and control the performance. Such a capability remains weak within the traditional organizations. This implies that organizations wishing to leverage the benefits of the gig economy must develop the processes to codify the work packages and the matching skills to be sourced from the gig platforms. Evidently, the organizations investing in such capabilities benefit from greater flexibility, scalability, and agility.

Another aspect of the gig economy is its retarding effect on the career and skill development of the gig worker [Kost et al., 2020]. As the organizations adapt their processes to integrate gig work, the skill profiles of their full-time employees must change from generalists to specialists skilled in controlling the outsourced work and managing the arms-length relationships with the gig workers. Traditional organizations structure the roles of their employees in accordance with the principles of division of labor, repetitive tasks, and hierarchical control. Integrating gig work implies considerable changes in the managerial and interpersonal skills of the full-time employees, and corresponding changes in the processes of selection, fitment, training, and performance management [Meijerink, Keegan, 2019].

Finally, it should be quite evident that the applicability of gig work will be non-uniform within the value chains. Areas such as new product development, product strategy, or branding maybe less amenable to platform-type gig outsourcing, compared to the relatively standardized and non-critical areas such as employee benefits, payroll, transportation, warehousing, website development, and so on. Traditional organizations following a 'one size fits all' design philosophy will find it challenging to switch to more flexible and agile designs for themselves, as they must overcome the hurdles posed by generating the consensus and the action within the existing person-organization fits.

\section{The Gig Economy in India}

India has recently witnessed a rapid rise in the gig economy in the recent years as evidenced by the mounting anecdotal evidence. India has emerged as the fifth largest country in the world for flexi-staffing behind the US, China, Brazil, and Japan, and had about 3 million gig workers in 2018. It estimates that this figure will rise to 6 million by end of $2021 .{ }^{10}$ It lists Banking, Financial Services, Insurance, Information Technology, and Retail as the major sectors absorbing the gig work. The growth of gig work is increasingly driven by large corporate companies who have begun to leverage independent consultants and freelancers to drive high-priority strategic projects and test new

\footnotetext{
${ }^{10} \mathrm{https} / /$ www.businessinsider.in/6-million-indians-will-be-in-the-gig-economy-within-two-years-thats-nearly-twice-the-current-size/articleshow/69854133.cms; accessed 21.07.2020
} 
product or service models [FlexingIt, 2019]. There has been a sharp growth in the registration of freelancers on the job portals, with $73 \%$ of the freelancers indicating that they do not intend to return to 9-to-5 full-time jobs [AppJobs, 2020]. While the emergence of the gig phenomenon is too recent to be comprehensively surveyed or studied by the researchers, the media articles suggest that the growth in the gig economy is driven by strong positive trends on both demand and supply sides.

From a demand perspective, gig work involves parcelling out short pieces of work with predefined outcomes by engaging workers on a non-permanent basis and paying them on the basis of the achievement of the outcomes. Thus, the ability to spin off work packages is critical for meeting demand for gig work. Most of the gig work until 2015 came from start-ups and small early-stage entrepreneurs. The recent entry of large corporate organizations trying to systemically reengineer the work processes imparts sustainability and robustness to the demand. Such reengineering involves the partitioning of all work into routine and non-routine categories, the careful reassessment of the work processes, and the development of managerial systems for engaging/outsourcing gig labor. Examples of routine work include processes related to ongoing functions such as production, sales, inventory management, and preventive plant maintenance. These activities require steady manpower to be engaged on a full-time employment basis. On the other hand, special projects or sporadic, one-time work do not require permanent manpower. Examples of such non-routine activities include the design of new products or services, market surveys and analysis, software development, process consultancy, occasional breakdown of specialized machinery, infrastructure or layout changes, and so on. In general, the organizations find it economical to engage the gig labor either because they do not possess the required expertise for such activities or do not have the economic justification for engaging such expertise on a full-time basis or the tasks being assigned for gig work are deemed sufficiently non-critical and low-valued [Howcroft et al., 2019].

Coming to the supply side of the labor economy, India historically has had a large workforce in the unorganized (also called informal) sectors. The informal sector employs more than $90 \%$ of the labor and contributes $50 \%$ to the GDP of the country [Government of India, 2012]. Agriculture and Forestry, Fishing, Trade, Hospitality, Community, Social and Personal Services, Real Estate and Construction, and Manufacturing are the leading sectors for absorbing unorganized labor. According to 2015 data, nearly $85 \%$ of the workforce were engaged without job contracts or contracts of less than one year [Government of India, 2014]. Given the large size of India's unorganized economy, it is no surprise that it has continued to draw attention from diverse interests from stakeholders such as policymakers, legislators, economists, lawyers, and tax authorities and has generated extensive studies. While specific surveys and studies about the gig economy remain sparse, available reports indicate that it is fairly sizeable and is experiencing rapid growth. It is believed that workers in an unorganized economy have a lowlevel or no qualification. Extant literature on the gig economy however cites choice and flexibility as key qualifying attributes to be a gig worker [Rosenblat, 2016]. Initially, gig workers were characterized as highly skilled professionals doing multiple short assignments as a way of earning their livelihoods. ${ }^{11}$ Since then, several authors have retained the attributes of diversity and skills and added the positive mediating effect of technology platforms on the gig phenomenon [Lepanjuuri et al., 2018; Gleim et al., 2019; Wood et al., 2019]. We argue that choice, flexibility, and intermediation by technology platforms are the key attributes of gig work. Consequently, those parts of the informal economy which lack the elements of voluntary choice and platform intermediation must be excluded from the gig phenomenon.

Since its independence, India's public policies have had a strong socialist orientation, and this has been reflected in its labor laws. Present-day India has wellinvested structures of labor laws for the protection of the workers from unfair and exploitative practices of employers. These laws were enacted in the times when industrial manufacturing was the dominant part of the formal economy, and the service sector was miniscule in size. With the passage of time, the manufacturing sector has contracted from $40 \%$ to less than $20 \%$, while services have grown to more than $50 \%$ of the country's GDP. However, the labor laws have not kept pace with the changing times and face criticism from several quarters that they are excessively restrictive and their pro-labor orientation is choking investments as well as growth in organized employment. Taking consideration of such criticism, the government has tried to bring in reforms of the labor laws, however this remains a work in progress, with experts claiming these attempts to be at best anaemic. ${ }^{12}$ The issue of informal sector workers is lost in the political crosswinds of change. All regulatory frameworks apply to the organized sector workers, leaving the very large number of informal sector workers unprotected against adverse practices by the employers.

TThe rapid rise of the gig economy is occurring in a legal landscape that has no regulation whatsoever and this exacerbates the issue of worker rights, protections, and social security. In 2018, the drivers of the ridehailing services in India went on a strike protesting the

\footnotetext{
${ }^{11}$ https://www.fastcompany.com/1222400/thriving-gig-economy, accessed 20.02.2020.

${ }^{12} \mathrm{https}$ //www.financialexpress.com/economy/covi19-labour-reforms-still-a-perennial-hot-potato-in-india/1991526/; accessed 26.07.2020

${ }^{13}$ https://www.reuters.com/article/us-uber-ola-strike/uber-ola-drivers-strike-in-india-demanding-higher-fares-idUSKCN1MW1WZ; accessed 26.07.2020
} 
compensation structures of Ola and Uber - two firms operating the intermediating technology platforms. ${ }^{13}$ In a paper on this issue, Surie [Surie, 2018] analyzes the nature of the engagement of these gig workers and argues for regulatory frameworks and bodies noting the potential for the exploitation of these workers.

The rapid rise of technology platforms and the gig economy has amplified the inequities of the labor situation. Unequal access to the internet and gender disparity in labor participation rates imply that several sections of the population have not been able to benefit from the gains of modern technologies. First, despite the rapid penetration of mobile telephony in India, the rural populations have generally not moved on from $2 \mathrm{G}$ telephony and thus lack good quality or high-speed access to the internet. This severely restricts their ability to engage in complex transactions. Second, the female population has not been able to participate in the gig economy, owing to multiple factors such as poorer literacy rates and technology illiteracy, familial responsibilities, and gender-determined social constraints. The issues of social security, workplace harassment, and contract enforcement transcend all segments of gig workers. A paper by the Indian think tank Observer Research Foundation notes dispute redressal, ombudsman of platforms, protection against workplace harassment, emergency button for physical safety, social security, and contractual protection as key areas for regulatory interventions [Kasliwal, 2020]. In summary, the growth of the gig economy in India holds considerable potential to address the endemic problem of employment generation and provides an impetus to the stalled process of reforms in India's labor laws. However, the promise of the gig phenomenon is unlikely to be delivered without enacting the necessary regulatory structures and legal frameworks.

\section{Model Development and Analysis Hypothesis Development}

We developed a model to relate the size of the gig economy in terms of the contextual macroeconomic variables. The platform-based economy is creating new value by monetizing economic resources such as assets and labor. We anticipate the availability of mobile, internet and broadband connectivity, and electricity connections to aid the gig labor economy. Accordingly, we propose the following hypothesis:

H1: The number of gig workers is positively influenced by the availability of internet, mobile, broadband subscriptions, and electricity connections.

Further, we posit that workers in the low-skill categories face high search costs for work and continued un- certainty in accessing opportunities. The emergence of technology platforms will induce such workers to join the gig economy by leveraging the technology infrastructure. We therefore hypothesize that the supply of gig workers would be higher when per-capita income levels are lower. Accordingly, we put forward the following hypothesis:

H2: Rising per capita income negatively influences the number of gig workers.

\section{Dependent Variable}

The dependent variable is the number of gig workers in the country. ILOSTAT published by the International Labor Organization (ILO) provides employment data by occupation and gender, segregated by different occupation categories. ${ }^{14}$ ILO estimates of employment by occupation categorize skills on four levels from level 1 (Low skilled) to level 4 (Professionals). ILOSTAT data suffers from several limitations. First, it reports data from conventional labor markets such as manufacturing and construction and does not cover gig workers. Second, a large proportion of professional workers such as university professors, doctors, and engineers are part of the organized labor markets and do not participate in the gig economy. Hence the ILOSTAT understates the estimates of professionals doing gig work. Third, ILO defines employment as worker employed for at least one hour in a week or a day [Hussmanns, 2007]. Such a measure fails to capture any collateral wage-earning work. For instance, if a worker employed full-time performs additional job(s), then such additional work is not counted in the employment statistics. Fourth, it is difficult to capture the value of gig work in areas such as product development, design, and marketing in published macro-economic data [Corrado, Hulten, 2010]. In general, the published macroeconomic data does not capture the online gig workers, even though such workers are large in number, especially in the developing countries.

To overcome these limitations, we use the Online Labor Index (OLI). ${ }^{15}$ This dataset offers gig economy-equivalent of the conventional labor market statistics. OLI tracks workers using labor market platforms across countries and occupations posted on major online gig platforms in near real time and provides the counts of workers engaged in gig labor. OLI is based on data by accessing websites through collection technologies such as application programming interface, scraping, or downloading the data from the digital platforms [Kässi, Lehdonvirta, 2018]. It uses data from unique visitor counts on leading gig platforms from Alexa ${ }^{16}$ and surveys of the top-five gig platforms: Upwork. com, Freelancer.com, Peopleperhour.com, Mturk.com,

\footnotetext{
${ }^{14}$ ILOSTAT: https://www.ilo.org/ilostat/faces/wcnav_defaultSelection;ILOSTATCOOKIE=CgBvIYKcLYPs-arXRjMILEuDcsbDiGtTJeGhbnE-zyGkRf4STSD1!595095360?_afrLoop=1828381741967760\&_afrWindowMode=0\&_afrWindowId=null; accessed on 14 May 2020

${ }^{15}$ Published by the Oxford Internet Institute. See: https://ilabour.oii.ox.ac.uk/online-labour-index/ accessed on 26 June 2020.

${ }^{16}$ Alexa's site popularity traffic rankings are based on the anonymous usage patterns of one of the largest and most global samples of internet users available in the world. See: https://aws.amazon.com/alexa-top-sites/; accessed on 02 January 2021

${ }^{17}$ Our data set is based on OLI surveys conducted in July 2016 and again in February 2017.
} 
Figure 2. Cumulative Proportions of Eigen Values

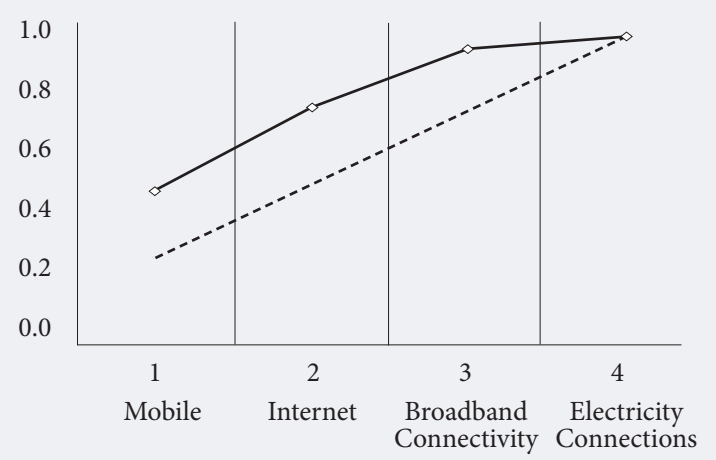

Source: compiled by the authors.

and Guru.com. ${ }^{17}$ It includes the following occupation classes: Professional services (such as accounting, consulting, legal, etc.), clerical and data entry, creative and multimedia (such as animation, logo design, etc.), sales and marketing support, software development and technology, and writing and translation. The OLI database is more exhaustive with many countries in the sample, and to our knowledge is the first database to give a comprehensive estimate of the number of gig workers.

\section{Explanatory Variables}

For explanatory variables, we propose ICT components namely: mobile telephony, internet access, broadband connectivity, and electricity connection. Other studies also point to the pivotal role of ICT in the gig economy [De Stefano, 2016; Aubert-Tarbey et al., 2018]. For instance, a joint study by the Foundation for European Progressive Studies and UNI Europa reports that $42 \%$ of the respondents had used online platforms to find services, including taxi drivers, builders, graphic designers, and accountants. ${ }^{18}$

To rule out the multicollinearity objections, we constructed a new variable, TI, by merging these four ICT variables. We take TI as an explanatory variable. Drawing from an earlier discussion in this paper, we expect the gig economy to positively affect the incomes of the gig workers. Gomez-Herrera et al. [GomezHerrera et al., 2017] find that workers from low-income countries are likely to participate in jobs offered by the high-income countries. ${ }^{19}$ Accordingly, we include log of per-capita income as an explanatory variable.

The data on mobile, internet and broadband connectivity, electricity connections, and per-capita income is taken from World Development Indicators [World Bank, 2017], detailing data about 139 countries. ${ }^{20}$

\section{Model}

We follow Ordinary Least Squares method to estimate the following equation:

$$
O L I_{i}=\alpha+\beta T_{i}+\gamma P C_{i} \text {, }
$$

Where, OLI refers to the online labor index, TI is the technology index, and PC refers to log of per-capita income. Subscript $i$ refers to the country.

\section{Results and Analysis}

Using Principal Component Analysis [Mardia et al., 1979], we construct TI as vector $X\left(X=X_{1}, X_{2}, \ldots, X_{4}\right)$ where, $X_{1}=$ mobile, $X_{2}=$ internet, $X_{3}=$ broadband subscription, and $\mathrm{X}_{4}=$ electricity connections. Before constructing TI, we standardize the data to ensure unit-free comparability among the data. The first principal component shows maximal variance of 1.94 and accounts for $48.5 \%$ variation among all regressors (Figure 2). It assigns weights of $0.65,0.35,0.66$, and 0.05 to $X_{p}, X_{2}, X_{3}$, and $X_{4}$ respectively. The high weights of broadband and internet connectivity indicate their relatively high relative importance within the technology infrastructure, while connectivity to mobile telephony and to electricity have moderate and low importance, respectively. The second principal component with a variance of 1.09 however accounts for only $27.3 \%$ of the total variation. We therefore retain TI with its weights as the variable for the regression. For each country, we then compute TI using the software package EViews 11.

Table 1 reports the findings from the regression analysis. The results support the hypothesis that technology infrastructure is significantly and positively related to the number of gig workers. The significant negative per capita income suggests that workers from low-income countries are induced to participate in the gig economy. The employers and the firms contracting out gig work are predominantly located in high-income countries, while the gig work can be outsourced to low-

Table 1. Gig Worker Index (Base Regression)

\begin{tabular}{|l|r|}
\hline \multicolumn{1}{|c|}{ Variable } & \multicolumn{1}{c|}{ Coefficient } \\
\hline Constant & $0.036^{* *}(0.017)$ \\
\hline Technology Index & $0.008^{*}(0.002)$ \\
\hline Per capita Income & $-0.003^{* * *}(0.001)$ \\
\hline R-squared & 0.14 \\
\hline Adjusted R-squared & 0.13 \\
\hline No. of Observations & 139 \\
\hline $\begin{array}{l}\mid l \\
\text { Note: Robust Standard Errors in Parenthesis; }{ }^{*} \mathrm{p}<0.01,{ }^{* *} \mathrm{p}<0.05,{ }^{* * *} \mathrm{p}<0.1 . \\
\text { Source: authors. }\end{array}$ \\
\hline
\end{tabular}

\footnotetext{
${ }^{18} \mathrm{http} / /$ englishbulletin.adapt.it/wp-content/uploads/2016/02/crowd-working-surveypdf1.pdf accessed on 26 June 2020

${ }^{19}$ Per-capita income follows log-normal distribution, with a vast majority of people earning low incomes.

${ }^{20}$ The World Bank classifies countries into three groups: low income, middle income, and high income. As of 1 July 2018 , low-income economies are defined as those with a gross national income (GNI) per-capita of $\$ 995$ or less in 2017; lower middle-income economies are those with a GNI per capita between $\$ 996$ and \$3,895; upper middle-income economies are those between $\$ 3,896$ and $\$ 12,055$; high-income economies are those with a GNI per capita of $\$ 12,055$ or more. For data source, see: https://databank.worldbank.org/data/download/WDI_excel.zip accessed on 26 June 2020.
} 
income countries [Gomez-Herrera et al., 2017; Song et al., 2019]. Within a particular country, as the evidence from the US suggests, high-skilled workers who already have traditional jobs are less likely to alter their behavior to search for gig work [Collins et al., 2019].

For robustness checks of the results, we perform sensitivity analysis [Levine, Renelt, 1992] by including additional explanatory variables to our base regression model: Manufacturing value-added to GDP and Service value-added to GDP. The results from the augmented regression show that the coefficients of manufacturing value-added to GDP and service value-added to GDP are insignificant.

\section{Conclusion}

The gig economy complements the traditional brickand-mortar economy by creating markets to exploit spaces that have remained inaccessible. The paper explores the drivers of the gig economy phenomenon and discusses its implications for labor productivity, employment, income distribution, and corporate strategies. As a case in point, we propose the hypothesis that the economics and the availability of ICT infrastructure moderate the supply of gig labor. We find that ICT infrastructure plays a pivotal role in the spread of the gig economy.

Given its ability to connect workers across the national boundaries, we find that such transnational reach does not lead to wage equalization. Rather, we find evidence of rising income disparity across lowskilled and highly skilled gig labor, indicating that the phenomenon impacts the different skill groups dif- ferently. At its intersection points with the traditional economy, businesses in sectors such as transportation, health, education, personal services, and the gig economy have caused displacement of brick-andmortar workers. Given our finding about the unequal benefits of the gig economy across activities and skill classes, the policymakers should evaluate appropriate regulatory or tax interventions. The policymakers also need to design interventions to address the needs of such displaced workers through retraining or through alternative employment opportunities.

A few limitations of our work can be readily acknowledged. First, while we find that technology infrastructure plays a significant positive role in the gig economy, there are empirical reports about the uneven spread of the phenomenon. It is necessary to go beyond the infrastructure and examine whether societal variables especially related to the ability to access and use such technology infrastructure exist. Second, the demand for gig work is influenced by governmental policies related to unemployment benefits. Cross-sectional analysis falls short of studying the policy impacts and will require longitudinal studies. Third, the differential absorption of technology infrastructure across occupations and age groups will require further studies to elicit the workings of the phenomenon. Finally, further research is necessary to understand how the skill levels of workers affect their participation in the gig economy.

This work is supported by the National Research Foundation of Korea Grant funded by the Korean Government (NRF2017S1A6A3A02079749).

\section{References}

AfDB, ADB, EBRD, IADB (2018) The Future of Work: The Regional Perspectives, Washington, D.C.: African Development Bank, Asian Development Bank, European Bank for Reconstruction and Development, Inter-American Development Bank. https://www.adb.org/sites/default/files/publication/481901/future-work-regional-perspectives.pdf, accessed 18.09.2020.

AppJobs (2020) Future of Work Report 2020, Stockholm: Future of Work Institute. https://irp-cdn.multiscreensite.com/ ec5bfac6/files/uploaded/AppJobs\%20Institute\%20Future\%20of\%20Work\%20Report\%202020.pdf, accessed 18.09.2020.

Aubert-Tarby C., Escobar O.R., Rayna T. (2018) The impact of technological change on employment: The case of press digitisation. Technological Forecasting and Social Change, 128, 36-45. https://doi.org/10.1016/j.techfore.2017.10.015

Banik N. (2019) Could Online Gig Work Drive Economic Growth? (KIEP World Economy Brief, 9 (17)). Sejong: Korea Institute for International Economic Policy. https://think-asia.org/bitstream/handle/11540/10903/WEB19-17.pdf? sequence=1, accessed 18.09.2020.

Bassanini A., Scarpetta S. (2002) Does human capital matter for growth in OECD countries? A pooled mean-group approach. Economics Letters, 74(3), 399-405. https://doi.org/10.1016/S0165-1765(01)00569-9

Berg J. (2016) Income security in the on-demand economy: Findings and policy lessons from a survey of crowd workers, Geneva: International Labor Office. https:/www.ilo.org/wcmsp5/groups/public/---ed_protect/---protrav/---travail/documents/ publication/wcms_479693.pdf, accessed 18.09.2020.

Bergman M.E., Jean V.A. (2016) Where have all the "workers" gone? A critical analysis of the unrepresentativeness of our samples relative to the labor market in the industrial-organizational psychology literature. Industrial and Organizational Psychology, 9(1), 84-113. https://doi.org/10.1017/iop.2015.70

Brodsky A., Amabile T.M. (2018) The downside of downtime: The prevalence and work pacing consequences of idle time at work. Journal of Applied Psychology, 103(5), 496-512. https://doi.apa.org/doi/10.1037/apl0000294

Card D., Heining J., Kline P. (2013) Workplace heterogeneity and the rise of West German wage inequality. The Quarterly Journal of Economics, 128(3), 967-1015. https://doi.org/10.1093/qje/qjt006 
Chandy L. (2017) The Future of Work in the Developing World (Brookings Blum Roundtable 2016 Post-Conference Report), Washington, D.C.: Brookings Institution.

Chaudhary M. (2019) Labour Practises in the emerging gig economy in India: A case study of Urban Clap. Paper presented at the CeMIS Formalisation, Informalisation and the Labour Process Workshop, 22 November, 2019, Goettingen, Germany. https://iwwage.org/wp-content/uploads/2020/02/Labour-Practises-in-the-emerging-gig-economy-in-India.pdf, accessed 26.06.2020.

Collins B., Garin A., Jackson E., Koustas D., Payne M. (2019) Is gig work replacing traditional employment? Evidence from two decades of tax returns (IRS SOI Joint Statistical Research Program Report), Washington, D.C.: Internal Revenue Service. https://www.irs.gov/pub/irs-soi/19rpgigworkreplacingtraditionalemployment.pdf, accessed 23.01.2021.

Connelly C.E., Gallagher D.G., 2006. Independent and dependent contracting: Meaning and implications. Human Resource Management Review, 16(2), pp.95-106. https://doi.org/10.1016/j.hrmr.2006.03.008

Corrado C.A., Hulten C.R. (2010) How do you measure a "technological revolution"?, American Economic Review, 100(2), 99-104. https://www.jstor.org/stable/27804971

De Stefano V. (2016) The rise of the «just-in-time workforce»: On-demand work, crowdwork and labour protection in the "gigeconomy», Geneva: ILA. https://www.onlabor.org/wp-content/uploads/2016/05/wcms_443267.pdf, accessed 23.01.2021.

Drahokoupil J., Fabo B. (2016) The platform economy and the disruption of the employment relationship (ETUI Research Paper-Policy Brief No. 5), Brussels: European Trade Union Institute. https://www.etui.org/sites/default/files/Platform\%20 economy\%20Drahokoupil\%20Fabo\%20Policy\%20Brief\%20PB\%202016.05.pdf, accessed 22.01.2021.

Edelman B.G., Luca M. (2014) Digital discrimination: The case of Airbnb.com (Harvard Business School NOM Unit Working Paper 14-054), Cambridge, MA: Harvard University Press.

Farrell D., Greig F. (2016) The online platform economy: Has growth peaked?, New York: JP Morgan Chase and Co. Institute. https://www.jpmorganchase.com/content/dam/jpmc/jpmorgan-chase-and-co/institute/pdf/jpmc-institute-onlineplatform-econ-brief.pdf, accessed 23.01.2021.

FlexingIt (2019) Professional Gig Economy - 2018-19 Report Card, New Delhi (India): FlexingIt. https://www.flexingit.com/ media/eoc_resume/professional-gig-economy-2018-19-report-card.pdf, accessed 16.01.2021.

Frenken K., Schor J. (2019) Putting the sharing economy into perspective. In: A Research Agenda for Sustainable Consumption Governance (ed. O. Mont), Cheltenham: Edward Elgar Publishing, pp. 121-136.

Gevers J.M., Rutte C.G., van Eerde W. (2006) Meeting deadlines in work groups: Implicit and explicit mechanisms. Applied Psychology, 55(1), 52-72. https://doi.org/10.1111/j.1464-0597.2006.00228.x

Gevers J., Mohammed S., Baytalskaya N. (2015) The conceptualisation and measurement of pacing styles. Applied Psychology, 64(3), 499-540. https://doi.org/10.1111/apps.12016

Gleim M.R., Johnson C.M., Lawson S.J. (2019) Sharers and sellers: A multi-group examination of gig economy workers' perceptions. Journal of Business Research, 98, 142-152. https://doi.org/10.1016/j.jbusres.2019.01.041

Gomez-Herrera E., Martens B., Mueller-Langer F. (2017) Trade, Competition and Welfare in Global Online Labour Markets: A ‘Gig Economy’ Case Study. SSRN Electronic Journal, 3090929. https://dx.doi.org/10.2139/ssrn.3090929

Government of India (2012) Informal Sector and Conditions of Employment in India, New Delhi: Government of India. http://mospi.nic.in/sites/default/files/publication_reports/nss_rep_539.pdf, accessed 23.07.2020.

Government of India (2014) Employment in Informal Sector and Conditions of Informal Employment, New Delhi: Government of India. https://labour.gov.in/sites/default/files/Report\%20vol\%204\%20final.pdf, accessed 26.07.2020.

Greenwood B.N., Wattal S. (2017) Show me the way to go home: An empirical investigation of ride sharing and alcohol-related motor vehicle fatalities. MIS Quarterly, 41(1), 163-187. https://doi.org/10.25300/MISQ/2017/41.1.08

Howcroft D., Dundon T., Inversi C. (2019) Zero Hours and On-call Work in Anglo-Saxon Countries. In: Fragmented Demands: Platform and Gig-Working in the UK. (eds. M. O’Sullivan, J. Lavelle, J. McMahon, L. Ryan, C. Murphy, T. Turner, P. Gunnigle), Heidelberg, New York, Dordrecht, London: Springer, pp. 215-232. https://doi.org/10.1007/978-981-136613-0_11

Huws U., Joyce S. (2016) Size of the UK's “Gig Economy” revealed for the first time (Crowd Working Survey Bulletin, February). Hertfordshire: UNI Europa, UH, http://englishbulletin.adapt.it/wp-content/uploads/2016/02/crowd-working-surveypdf1. pdf, accessed 26.06.2020.

ILO (2018) Digital Labour Platforms and the Future of Work, Geneva: ILO. Available at https://www.ilo.org/wcmsp5/groups/ public/---dgreports/---dcomm/---publ/documents/publication/wcms_645337.pdf, accessed 23.07.2020.

Kalleberg A.L., Dunn M. (2016) Good jobs, bad jobs in the gig economy. LERA for Libraries, 20(1-2), 10-14. http://lerachapters. org/OJS/ojs-2.4.4-1/index.php/PFL/article/viewFile/3112/3087, accessed 23.07.2020.

Kasliwal R. (2020) Gender and the Gig Economy: A qualitative study of gig platforms for women workers (ORF Issue Brief No. 359, May 2020), New Delhi: Observer Research Foundation. https://www.orfonline.org/research/gender-and-the-gigeconomy-a-qualitative-study-of-gig-platforms-for-women-workers-65948/, accessed 26.06.2020.

Kässi O., Lehdonvirta V. (2018) Online labor index: Measuring the online gig economy for policy and research. Technological Forecasting and Social Change, 137, 241-248. https://doi.org/10.1016/j.techfore.2018.07.056

Kenney M., Zysman J. (2016) The rise of the platform economy. Issues in Science and Technology, 32(3), 61-69. https://issues. org/the-rise-of-the-platform-economy/, accessed 26.06.2020. 
Kost D., Fieseler C., Wong S.I. (2020) Boundaryless careers in the gig economy: An oxymoron?. Human Resource Management Journal, 30(1), 100-113. https://doi.org/10.1111/1748-8583.12265

Kumar A.P. (2019) Code on Wages and the Gig Economy. Economic and Political Weekly, 54(34), 10-11. https://www.academia. edu/40858085/Code_on_Wages_and_Gig_Economy, accessed 26.06.2020.

Lepanjuuri K., Wishart R., Cornick P. (2018) The characteristics of those in the gig economy, London: UK Department for Business, Energy and Industrial Strategy.

Levine R., Renelt D. (1992) A sensitivity analysis of cross-country growth regressions. American Economic Review, 82(4), 942-963. https://www.jstor.org/stable/2117352

Lobel O. (2016) The Gig Economy \& The Future of Employment and Labor Law (San Diego Legal Studies Paper No. 16-223). https://ssrn.com/abstract=2848456, accessed 26.06.2020.

Manyika J., Lund S., Bughin J., Robinson K., Mischke J., Mahajan D. (2016) Independent-Work-Choice-necessity-and-the-gigeconomy, New York: McKinsey Global Institute.

Meijerink J., Keegan A. (2019) Conceptualizing human resource management in the gig economy: Toward a platform ecosystem perspective. Journal of Managerial Psychology, 34(4), 214-232. https://doi.org/10.1108/JMP-07-2018-0277

Pandya U., Rungta R., Iyer G. (2017) Impact of Use of Mobile App of OLA Cabs and TAXI for Sure on Yellow and Black Cabs. Pacific Business Review International, 9(9), 91-105. http://www.pbr.co.in/2017/2017_month/March/11.pdf, accessed 26.06.2020.

Rosenblat A. (2016) What motivates gig economy workers. Harvard Business Review, 11, 2-5. https://hbr.org/2016/11/whatmotivates-gig-economy-workers, accessed 26.06.2020.

Schmenner R.W., Swink M.L. (1998) On theory in operations management. Journal of Operations Management, 17(1), 97-113. https://doi.org/10.1016/S0272-6963(98)00028-X

Sherk J. (2009) What Unions Do: How Labor Unions Affect Jobs and the Economy, Washington, D.C.: The Heritage Foundation. http://s3.amazonaws.com/thf_media/2009/pdf/bg2775.pdf, accessed 26.06.2020.

Song J., Price D.J., Guvenen F., Bloom N., von Wachter T. (2019) Firming up inequality. Quarterly Journal of Economics, 134(1), 1-50. https://doi.org/10.1093/qje/qjy025

Surie A. (2018) Are Ola and Uber drivers entrepreneurs or exploited workers. Economic and Political Weekly, 53(24), 1-7. https://www.epw.in/node/152009/pdf, accessed 26.06.2020.

Tran M., Sokas R.K. (2017) The gig economy and contingent work: An occupational health assessment. Journal of Occupational and Environmental Medicine, 59(4), e63-e66. https://dx.doi.org/10.1097\%2FJOM.0000000000000977

van Doorn N. (2017) Platform labor: On the gendered and racialized exploitation of low-income service work in the 'on-demand'economy. Information, Communication and Society, 20(6), 898-914. https://doi.org/10.1080/136911 8X.2017.1294194

von Scheel H., Bogebjerg A.F. (2012) Innovating a Turnaround at LEGO. In: The Complete Business Process Handbook: Leading Practices of the Outperformers, vol. 3 (Leading Practices from Outperformers) (eds. M. von Rosing, H. von Scheel, A.W. Scheer), Berlington, MA: Morgan Kaufmann. https://www.researchgate.net/publication/329464422_Innovating_a_ Turnaround_at_LEGO, accessed 26.06.2020.

Wood A.J., Graham M., Lehdonvirta V., Hjorth I. (2019) Good gig, bad gig: Autonomy and algorithmic control in the global gig economy. Work, Employment and Society, 33(1), 56-75. https://doi.org/10.1177\%2F0950017018785616

World Bank (2015) The global opportunity in online outsourcing, Washington, D.C.: World Bank Group. http://documents. worldbank.org/curated/en/138371468000900555/The-global-opportunity-in-online-outsourcing, accessed 26.06.2020.

Zhao Y. (1999) Labor migration and earnings differences: The case of rural China. Economic Development and Cultural Change, 47(4), 767-782. https://doi.org/10.1086/452431 